UDC 378:004.9

\title{
Yuriy D. Zhukov
}

Doctor of Technical Sciences, Professor, Head of Marine Instrumentation Department

Admiral Makarov National University of Shipbuilding, Mykolaiv, Ukraine

ORCID 0000-0002-7454-8007

prof.zhukov@gmail.com

\section{Hanna Yu. Haidai}

$\mathrm{PhD}$ of Technical Sciences, Associate Professor at the Department of Marine Instrumentation

Admiral Makarov National University of Shipbuilding, Mykolaiv, Ukraine

ORCID 0000-0002-2516-7080

russish999@gmail.com

\section{Oleh O. Kudin}

Lecturer at the Department of Marine Instrumentation

Admiral Makarov National University of Shipbuilding, Mykolaiv, Ukraine

ORCID 0000-0003-3334-0012

oleg.alekseevich.kudin@gmail.com

\section{THE CURRENT STATE AND PROSPECTS OF THE USE OF DISTANCE LEARNING INSTRUMENTS DURING STUDY SHIP ENGINEERING}

\begin{abstract}
The paper is focused on identifying the advantages and disadvantages of remote education systems in terms of modern requirements to practical skills of future professionals, especially in the engineering field. Based on the analysis of the shortcomings of the already existing distance education models in the context of the pandemic, the need for a fundamentally new remote training scheme has been substantiated. The proposed model allows the students and interns of the shipbuilding profile to master the theoretical backgrounds of shipboard design and engineering and complete all practical tasks, acquiring practical skills in specialized packages of up-to-date shipbuilding CAD systems entirely remotely.This model was tested using a peer-to-peer data exchange technology between three modern information platforms: Moodle, CADMATICTM and TeamViewer. Advantages of this distance learning model were identified: the possibility of acquiring practical skills in modern computer-aided design systems from anywhere globally through direct interaction of the learner and the teacher in real-time. An appropriate engineering education approach has been developed based on the presented model, enabling the student to acquire needed practical skills and initial experience in ship design using modern threedimensional $\mathrm{CAD}$ in remote mode. The described course prepares the trainees for work at shipbuilding design and production companies in initial engineering positions, namely in ship hull design, structural digital twins, and production information development. A pilot project, "Development and testing of specialised multimedia courses in advanced ship engineering", was implemented at the "Neoteric Naval Engineering Institute" of the Admiral Makarov National University of Shipbuilding. The project results show the high efficiency of using the proposed engineers training model considering modern requirements of employers to future designers and the commercial safety requirements of shipbuilding CAD systems suppliers. The relevance of the results obtained is justified both in the context of the COVID-19 pandemic and beyond.
\end{abstract}

Keywords: distance learning; ship design; computer-aided design; learning model; engineering education; digital twins.

\section{INTRODUCTION}

The problem statement. In recent years, the application of distance learning in the global higher education system has risen sharply. Many Ukrainian young people aspire to a European level of education, but this is often hindered by the cost of full-time study and living in another city or country [1]. It is worth mentioning that modern online education allows international students and interns to study conveniently from any place in the world. 
However, this type of education also has several significant shortcomings, examined in detail in the paper. Today, in the context of the current coronavirus pandemic, the issue of quality distance education has become particularly acute (as reflected in [2], [3]), especially in the field of forming practical engineering skills.

Analysis of recent studies and publications. According to the data given in [4], the first open online course appeared about ten years ago, when a Canadian teacher from the University of Manitoba launched the first online course, "Connectivism and Connective Knowledge". The increasing number and popularity of this type of course responded to the shortcomings and omissions of the traditional educational system [5], namely, the high cost of obtaining quality higher education, the lack of competent teachers, obsolete material, and outdated methods of information handling.

The analysis of information sources in this area, such as [6], [7], [8], shows that most online courses are an attempt to simply transfer the university "long education" to the online format, i.e. topics, structure of lectures, the time frame and forms of control have been preserved. In general, the way the teacher and the student communicate has changed, and the model of face-to-face information exchange has been replaced by online communications. Thus, the transfer of courses from universities to the Internet has made knowledge more accessible but has not solved the problems of practical professional training of students.

According to the works [4], [9], the more structured and flexible online learning is, the more effective it is. With minimal time costs, it is possible to expand considerably the list of competencies, which gives a significant advantage in finding a new job. Therefore, the improvement and modification of course structure and inclusion of materials oriented towards development of practical professional skills have become more active [10], [11]. As a result, knowledge is acquired to be immediately applied in practice with a small amount of additional information. The most popular online tutorials of a kind are Udacity, Udemy, Lynda [12] etc.

Furthermore, it is worth noting that one of the main benefits of online education is the dynamics of the transmitted knowledge changes [13]. The current development of science and technology is so rapid that new textbooks and manuals do not keep up at this pace. The online format allows updating much more frequently so that the appropriate learning materials remain relevant for as long as possible.

Some of the world's most famous online platforms are Coursera, OpenedX, Udacity, Udemy, Lynda and SkillShare [12]. Coursera and OpenedX services resemble ordinary academic education and attempt to recreate university education online and make it more accessible. Their theoretical courses are not much different from universities' counterparts in structure and content. Udacity, Udemy, Lynda, and SkillShare represent a slightly different direction where the main content is practical video lectures, master classes, and tutorials from practitioners and professionals in their field. An attractive feature of these services is the possibility to acquire specific practical skills or knowledge quickly.

Ukrainian online education began its development in 2013 with the Prometheus project, an online platform based on OpenedX, followed by EdEra [4]. These platforms relate to distance online education of the so-called "academic type". In 2015, the EDUGET project was launched, implementing a professional-oriented approach to help users acquire the practical skills needed in the labour market [12].

The specific problem that causes the necessity of the research is as follows. The existing online education services and courses provide basic and advanced knowledge through electures and video lessons but not practical skills to use complex CAD systems or packages. Typically, a student can interact directly with a teacher while studying theoretical material. But to perform practical professional training, the user needs to view a video lesson, where clear instructions for performing the work are described, then execute it him/herself and 
present to the teacher the final result for control. But this model cannot be used with very complex and expensive shipbuilding CAD/CAM/CAE systems installed only on special servers located in a training centre, shipyard, or design office. System providers do not allow uncontrolled licenses, and faculty are responsible for their non-commercial use; students cannot afford even to rent the software needed.

Furthermore, the efficiency of gaining the skills in ship engineering without teacherstudent interaction in real-time showed its inefficiency in more than ten years of the authors' experience. At first, the student watches the laboratory work demo video and then may discuss it with the teacher and answer questions. But then the student still needs to come to the university to perform the task using corresponding hardware and software in the laboratory. However, this option is not acceptable for many students or interns, especially for learners from another city or abroad - to say nothing about distance learning in quarantine conditions.

The authors' own practical experience and comments of graduates' employers clearly showed that the lack of students' direct interaction with skilled professionals precisely when acquiring practical work skills is a significant shortcoming of modern distance education.

The research goal. The purpose of this article is to develop an appropriate model of engineering education for the shipbuilding industry in a distance mode using modern computer-aided ship design and construction tools during and after the COVID-19 pandemic. Another objective is to present results of testing of the new remote education model by some students and interns at the Neoteric Naval Engineering R\&D Institute (NNEI) of the Admiral Makarov National University of Shipbuilding (NUS). The main research goal is to provide conformity of the achieved level of practical skills of training course graduates with the highest requirements of their potential employers and also commercial safety of leading suppliers of shipbuilding CAD/CAM/CAE systems.

\section{RESEARCH METHODS}

The latest scientific articles, research publications, educational literature, and currently operational electronic resources were analysed in this work. Theoretical methods used include methods of analysis, synthesis and analogy, and statistical methods of assessing the results of learners' activities.

The analysis of pedagogical literature and scientific sources allowed the authors to generalize the existing remote education systems structures, identify the main advantages and disadvantages of using such systems, and trends in their rapid development.

Methods of analogy and synthesis based on the method of analysis allowed the authors to develop a new distance learning model. It is similar to existing models in terms of the overall structure of such systems but differs from them in its functionality and learning outcomes, providing students with practical skills.

Empirical methods were based on a detailed study of the distant education process, as well as the final results of students' distance learning according to the new model, which is presented in this paper. All these were considered in terms of practical engineering skills that students acquired completing the training course to be competitive in today's labor market.

\section{THE RESULTS AND DISCUSSION}

Before turning to the main results of this work, we consider it appropriate to specify that this article primarily concerns the possibility of carrying out remote engineering education. The presented research is conducted in the area where the most significant number of 
difficulties arose before and during the coronavirus pandemic, which is detailed in table 1 . However, the material presented in the article can also be used in any other fields of distance education.

Table 1

Problems of providing engineering education in a remote mode

\begin{tabular}{|l|l|}
\hline \multicolumn{1}{|c|}{ Problems } & \multicolumn{1}{c|}{ Causes } \\
\hline $\begin{array}{l}\text { Difficulties in using modern application software, in } \\
\text { particular computer-aided design systems, remotely }\end{array}$ & $\begin{array}{l}\text { - high cost of such system licenses for students; } \\
- \text { high system requirements that are unattainable for } \\
\text { personal computers and laptops used by the average } \\
\text { student; } \\
\text {-unavailability of free access to training materials } \\
\text { for work in modern computer-aided design systems. }\end{array}$ \\
\hline $\begin{array}{l}\text { Difficulties in data protection and security of } \\
\text { application software licenses, in particular computer- } \\
\text { aided design systems }\end{array}$ & $\begin{array}{l}\text { - high cost of proprietary software for organizing } \\
\text { VPN channels for budget organizations; } \\
\text { access VPN. }\end{array}$ \\
\hline $\begin{array}{l}\text { Impossibility to perform laboratory work in real time } \\
\text { mode, and, as a result, the impossibility of obtaining } \\
\text { practical engineering skills while studying the course }\end{array}$ & $\begin{array}{l}- \text { the ability to place only videos and electronic } \\
\text { tutorials for any practical or laboratory works in } \\
\text { university distance learning systems, such as } \\
\text { Moodle, GoogleClassroom, etc.; } \\
- \text { the impossibility of direct remote interaction } \\
\text { between the student and the teacher during the } \\
\text { training for the reason stated above. }\end{array}$ \\
\hline
\end{tabular}

Considering distance education as the most modern and efficient form of acquiring knowledge, professional capabilities, and skills [14] and a necessary form of education under quarantine conditions [3], the authors propose a unique online training course, which was entirely carried out in a remote format.

Efficiency of the proposed training model was tested during one of most important courses "Basics of Ship Engineering" taught at NNEI at NUS. As stated earlier (see table 1), the practical orientation of this discipline poses some difficulties in developing professional skills remotely. Specifically, the course involves carrying out a three-dimensional simulation of a vessel in one of the modern shipbuilding CAD Systems, CADMATIC ${ }^{\text {TM }}$ or any other CAD such as AVEVA ${ }^{\mathrm{TM}}$ Marine, E3D, etc. [15]. Moreover, the cost of one license of this kind of systems is unaffordable for one student or even for a group of students who intend to take a course in these or a similar system.

In conditions of modern industry and global digitalization, to be competitive in shipbuilding labour market the graduates of the shipbuilding universities (the future design and construction engineers in most Ukrainian and foreign shipyards and design offices) have to get the following practical skills:

- ability to work in modern shipbuilding CAD packages;

- ability to use CAD tools to create a three-dimensional hull structure according to all the requirements for such structures;

- knowledge of high-quality design documentation in the CAD environment;

- ability to develop a ship design, considering the customer requirements;

- analysis of the obtained results for timely detection and correction of various errors.

As a solution to research goals of the paper, the authors propose to use simultaneously three computer applications during distance learning: Moodle, CADMATICTM, and TeamViewer. At the same time, the Moodle [16] system allows the implementation of the theoretical part of the course entirely and performs the testing of the knowledge level through intermediate and control testing. 
The CADMATIC ${ }^{\text {TM }}$ system [17] provides a practical part (laboratory works) of the course (fig. 1). TeamViewer service [18] gives learner-controlled access to the workstation on which the CADMATICTM system is installed, remotely from anywhere in the world. Here, it is appropriate to note that TeamViewer is not the only one to be used within the proposed model - it is also possible to use similar applications, such as Chrome Remote Desktop, Getscreen.me, AnyDesk, etc.

The main advantages and disadvantages of this type of utility, which is most often used in practice [19], are given in table 2. Similarly, instead of Moodle, it is possible to use any of its analogues, for instance, Google Classroom, OpenedX, Udemy [20], etc. [20].

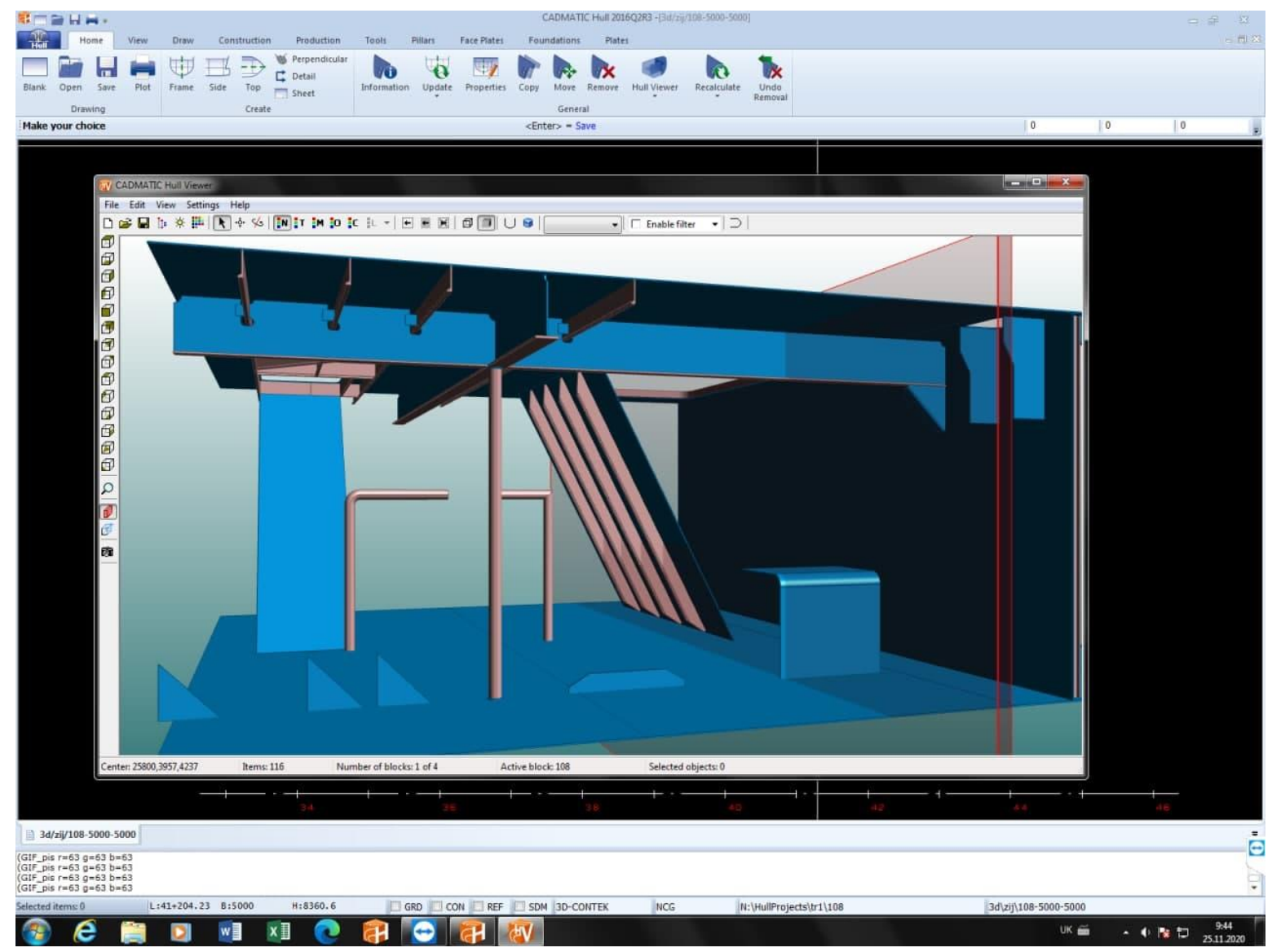

Figure 1. Practical work in CADMATIC ${ }^{\mathrm{TM}}$ (screenshot)

As can be seen from table 2, each of the presented programs can be used for remote access while providing distance learning. But it should be noted that the first two systems (TeamViewer and AnyDesk) meet all the system and functional requirements. At the same time, the TeamViewer program is the most functional, popular, and widespread among such services, so it was used in the proposed scheme.

However, in our opinion, AnyDesk is the worthiest analogue of the previous program. The last three services: Chrome Remote Desktop, Getscreen.me and Microsoft Remote Desktop have significant shortcomings, so their using, according to the authors, has significant limitations in certain circumstances.

Regarding the use of the three-dimensional CADMATIC system in the course "Basics of Ship Engineering", which gives the possibility to obtain practical engineering skills by future designers, we must highlight the following [17]: 
- CADMATIC is currently one of the leading CAD in the global shipbuilding market and has more than 950 users in 57 countries (world-famous system users such as DAMEN, Wartsila, Ulstein, Oshima, IHC Holland, STX Finland Cruise, etc.);

- the system is used in commercial, military shipbuilding and yacht construction;

- the system is open and has a flexible interface;

- short training period to use the system;

- high speed of creating a three-dimensional model in the system (30\% faster than in similar systems).

Table 2

Comparative table of software for remote access to the computer

\begin{tabular}{|c|c|c|}
\hline Program name & Advantages & Disadvantages \\
\hline TeamViewer & $\begin{array}{l}\text { - easy connection; } \\
\text { - the ability to record the current } \\
\text { session video; } \\
\text { - fast data transfer between } \\
\text { computers; } \\
\text { - high security level with two-level } \\
\text { authentication; } \\
\text { - cross-platform; } \\
\text { - stable work; } \\
\text { - VPN connection support. }\end{array}$ & $\begin{array}{l}\text { - requires running on both } \\
\text { computers; } \\
\text { - use of only one server. }\end{array}$ \\
\hline AnyDesk & $\begin{array}{l}\text { - almost all major platforms support; } \\
-\quad \text { computer protection from } \\
\text { unauthorized access; } \\
\text { - low delay and fast data transfer; } \\
\text { - no restrictions in the free version; } \\
\text {-several remote desktops work on } \\
\text { separate tabs. }\end{array}$ & $\begin{array}{l}\text { - less functionality compared to } \\
\text { the previous program. }\end{array}$ \\
\hline Chrome Remote Desktop & $\begin{array}{l}\text { - security; } \\
\text { - free of charge; } \\
\text { - there is no need to install additional } \\
\text { software if you use the Chrome } \\
\text { browser; } \\
\text { - stable and fast work; } \\
\text { - availability for all major platforms. }\end{array}$ & $\begin{array}{l}\text { - limited functionality; } \\
-\quad \text { there is no file transfer } \\
\text { possibility. }\end{array}$ \\
\hline Getscreen.me & $\begin{array}{l}\text { - the ability to work with a remote } \\
\text { computer either from the phone or } \\
\text { from another computer; } \\
\text { - simultaneous connection; } \\
\text { - without a separate IP-address work. }\end{array}$ & $\begin{array}{l}\text { - the free version restriction } \\
\text { (connection lasts no more than } 15 \\
\text { minutes); } \\
\text {-the size of the file being } \\
\text { transferred limitation (up to } 50 \\
\text { MB). }\end{array}$ \\
\hline Microsoft Remote Desktop & $\begin{array}{l}\text { - the RDP protocol used for access is } \\
\text { sufficiently secured and it works } \\
\text { well; } \\
\text { - does not require any additional } \\
\text { software installation. }\end{array}$ & $\begin{array}{l}\text { - can be connected to a computer } \\
\text { running only Windows Pro or } \\
\text { higher; } \\
-\quad \text { without additional settings } \\
\text { works only with computers that } \\
\text { are on the same local network or } \\
\text { have static IP on the Internet. }\end{array}$ \\
\hline
\end{tabular}

Here we have to emphasize that other software packages similar to CADMATIC may be used for the above and other ship design or engineering training courses. For example, it can be such systems as AVEVA Marine or SIEMENS NX, etc., each occupying leading positions in the digitalization and automation of the production processes in different shipyards. 
In our opinion, it is also an essential fact that when users work with the CADMATIC ${ }^{\text {TM }}$ system on the server where the system is installed, a particular protocol file of their work is recorded: dm_nlc_log.txt. This record is a single row consisting of the following fields: date and time of user disconnection from the server; date and time of connection to the server; computer's conditional name; username in the operating system of the workstation and server access control system; name of the CADMATIC module; the number of hours and minutes worked. For example, the following line is generated:

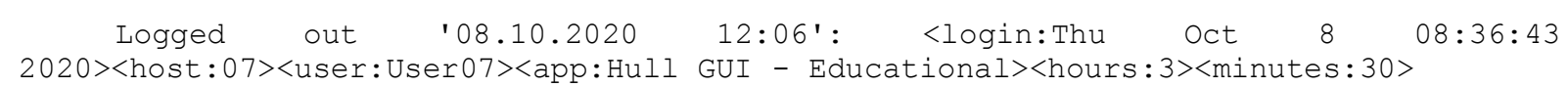

The file is stored on the server at:

- C: \Program Files \Cadmatic \Licence Server.

Thus, this file provides the teacher with all the necessary information about the student's actual work during distance learning and training in "Basics of Ship Engineering".

As already mentioned, the course itself is on one of the Moodle NUS Remote Education Servers (fig. 2).

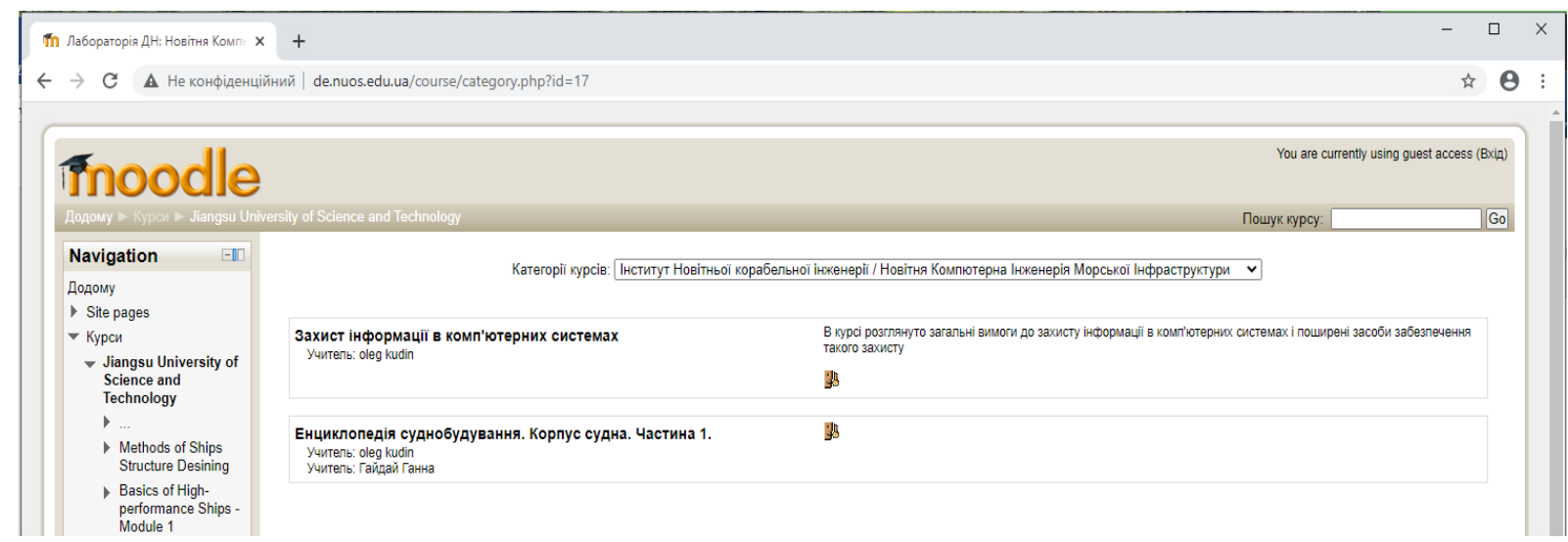

Figure 2. General view of the web browser window (screenshot)

After the beginning of the course, each student receives a password from the teacher to access the system or its parts. The student can view the e-lecture materials and the methodological instructions, and video lessons for preparation for laboratory training work (fig. 3). The printed version of these training materials is presented in the authors' publications [21], [22].

After completing each topic, the student takes an intermediate test, which is the main condition for admission to the relevant laboratory work, and after completing the course, a control test, which is one of the conditions for admission to the graduation work.

Thus, in the study of theoretical provisions (access to the text of lectures and methodological instructions) and when getting acquainted with the process of performing laboratory work (access to instructional video lessons) the Moodle Remote Learning Control System is used to create 3D models of hull sections.

However, to perform the laboratory works directly in the CADMATIC CAD (or any other CAD) environment, it is necessary to use another interaction model with the student based on the developed pattern (fig. 4). 


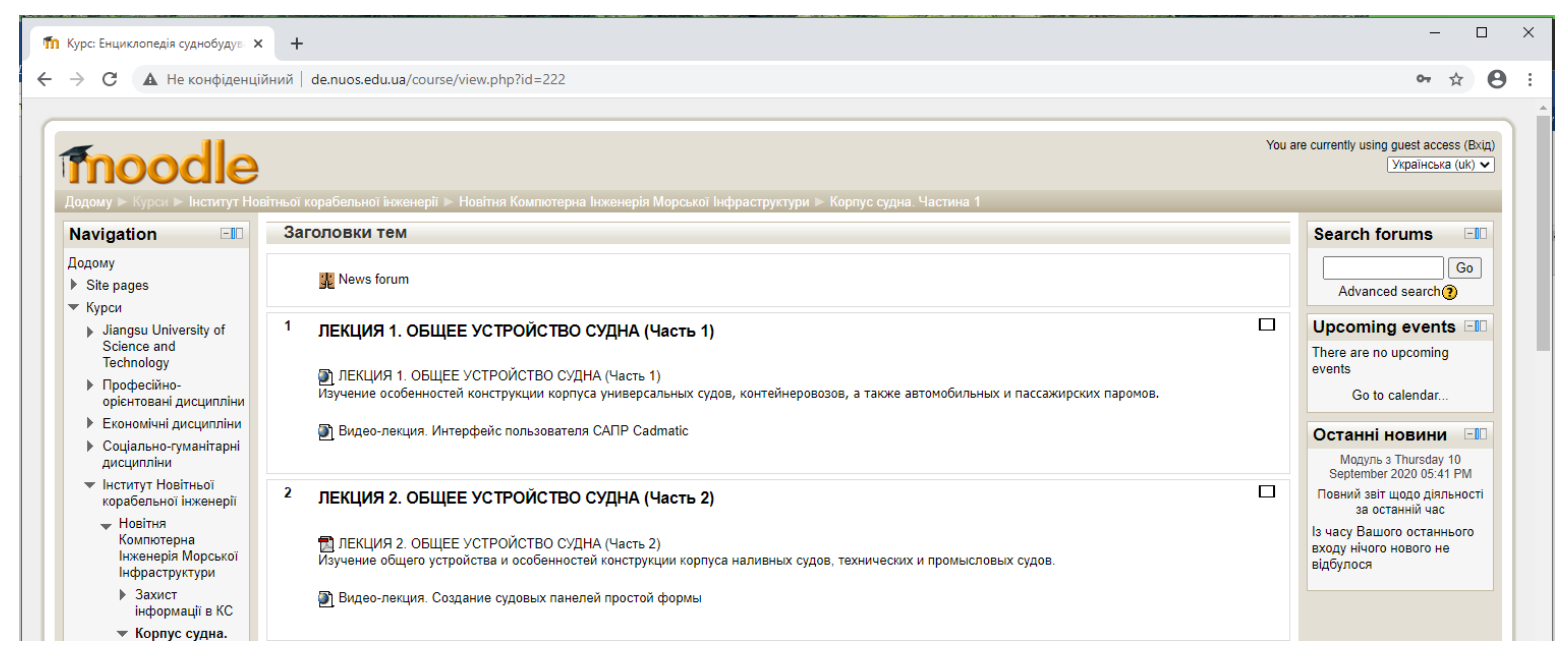

Figure 3. Remote Course Material Viewer (screenshot)

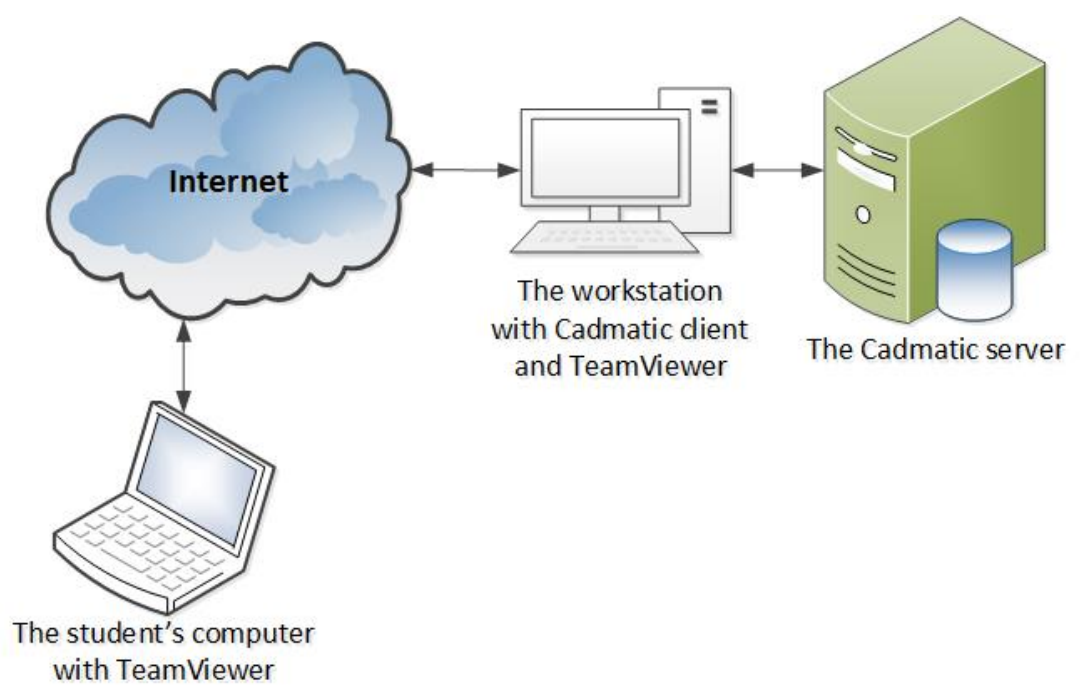

Figure 4. Proposed and tested secure CADMATIC ${ }^{\mathrm{TM}}$ Remote Training Scheme

According to the scheme mentioned above, the student's computer is connected to the CADMATIC ${ }^{\text {TM }}$ workstation located in the NNEI at NUS, with TeamViewer application (or its analogues). The same program has been installed at the workstation. The data for setting up a practical session (workstation ID and password) is passed to the student by the teacher through communication means (mobile phone, SMS, Viber, Zoom, Skype, etc.). Once connected to the workstation, the students launch the CADMATIC ${ }^{\text {TM }}$ client and perform laboratory tasks under the tutor's supervision following pre-studied video lessons and methodological guidelines of work principles and procedure.

An important feature distinguishing the scheme from that applied in industry is the following. The Shipbuilding Design Bureau uses a remote workstation connection scheme based on VPN (Virtual Private Network) technology. As a rule, proprietary software is used to organize VPN channels, which a higher education institution cannot always acquire due to its high cost for budget organizations. Open access VPN can provide direct access to the CADMATIC system, which does not provide adequate data protection and security for the expensive CADMATIC licenses stored on the server. The proposed model uses secure communication protocols embedded in TeamViewer (or its analogues). This model makes it 
possible for any student who has been granted access to the CADMATIC system to connect easily and quickly from their computer with proper server data protection [23].

The main advantage of this model, in our opinion, is not just the possibility of students' real work in a modern license system of three-dimensional ship design in a remote mode. They are still working under the teacher's complete control as if working directly in a classroom. Thus, students from anywhere in the world do laboratory work, and a university professor monitors everything on their computer screen. If students have some questions, make a mistake, or choose an ineffective path, the teacher will answer the questions and be able to correct the students' work. And this will be done in real-time by commenting on the situation using a mobile phone, SMS, Viber, Zoom, Skype, etc. If necessary, however, the teacher may take direct control of the system.

Thus, the above model of distance engineering education was applied to the developed model of realizing online learning of ship engineering fundamentals utilizing modern information systems. This model was successfully tested and implemented in the NNEI Training Centre at the NUS in the course "Basics of Ship Engineering" and the training courses for future designers in shipbuilding. All NNEI graduates were awarded relevant certificates, which helped them to find employment in ship design offices in Ukraine and abroad.

The screen view of the PC with the CADMATIC client running is shown in fig. 5.

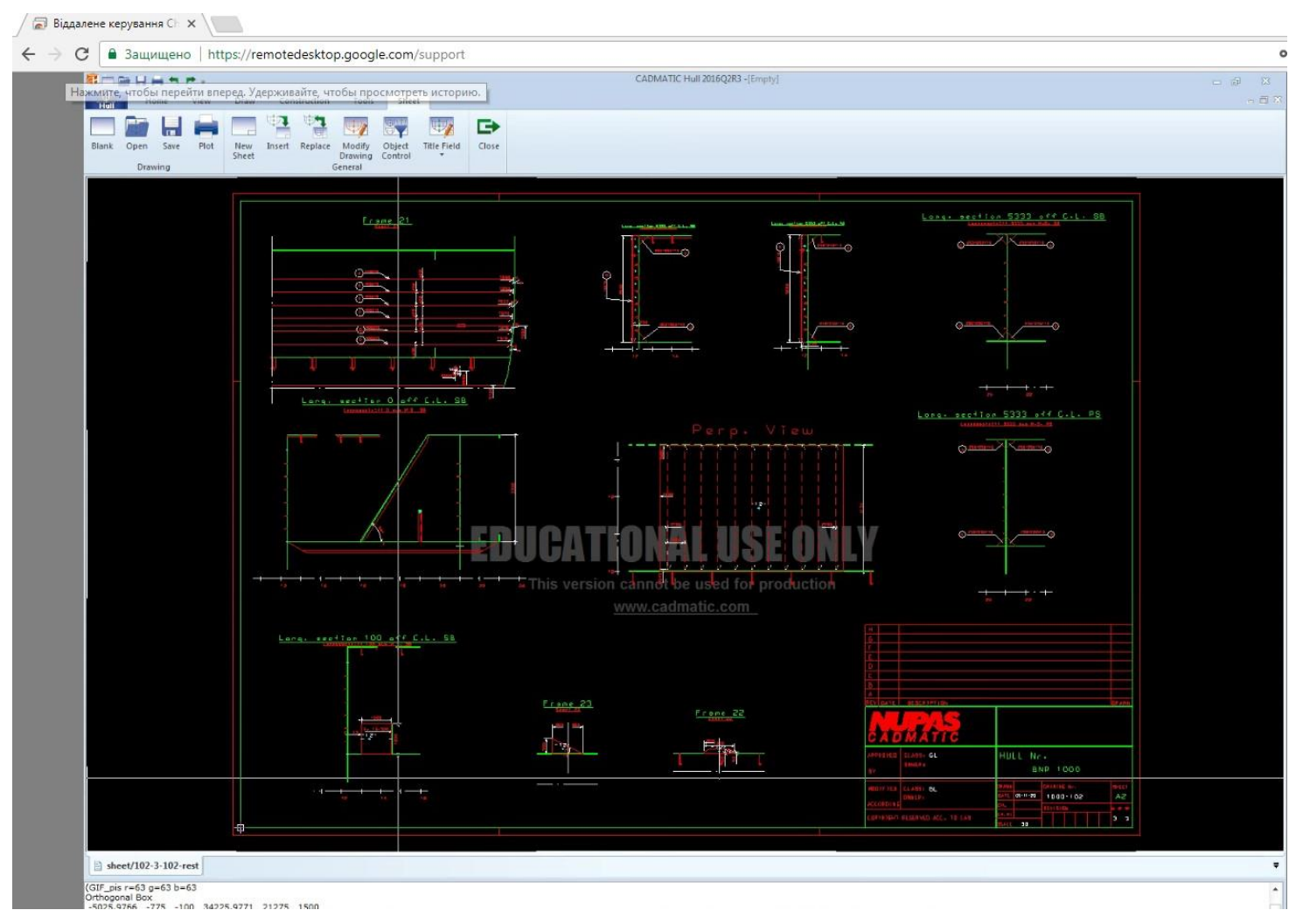

Figure 5. Remote Desktop View of CADMATIC Application (screenshot)

Considering the discipline "Basics of Ship Engineering" in terms of remote access, it should also be noted that this course is part of the automated distance learning system (DLS) "The Advanced Naval Engineering", and the above model of distance learning became the basis for one of the main system modules. The system is built on a modular principle to realize the possibility of its expansion and modernization without redesigning the system as a whole. DLS consists of the following modules: 
1. The control module of the system as a whole. The main module task is to perform the functions of administration and control of other modules and users of DLS.

2. Knowledge base of the system. One of the main tasks of this DLS is to gain experience of advanced design bureaus in the modern ship design and provide access to this experience for the students and interns of the course. The knowledge base is designed to accomplish the task.

3. Data exchange module with knowledge base. DLS users may have requests, different in content and structure, to obtain information stored in the knowledge base. This module is designed to generate reports based on user requests.

4. Module for recording, correcting and deleting educational content. This module is responsible for creating and improving training materials hosted in the Moodle system.

5. Learning process management module. This module solves the problem of timely reminding students about the relevant educational activities, accumulates information about students' activity in the system, as well as the level of knowledge obtained by them, etc.

6. Data analysis and reporting module. The module is designed for a comprehensive analysis of student participation in the distance learning process and reporting.

7. Data exchange module between CAD/CAE systems and CAM systems of a shipyard. The module is designed for remotely gaining complete set of practical experience in solving engineering tasks using up-to-date software platforms by self-training course participants.

Table 3 contains a list of laboratory work topics on the course "Basics of Ship Engineering", as well as the topic of the graduation work [22].

Laboratory workshop on the course "Basics of Ship Engineering"

\begin{tabular}{|c|c|c|}
\hline Work type & Topic of the work & Preparation and admission \\
\hline Laboratory work № 1 & $\begin{array}{l}\text { The hull partitioning into separate } \\
\text { compartments in CADMATIC } \\
\text { CAD taking into account the } \\
\text { requirements for strength and } \\
\text { unsinkability }\end{array}$ & $\begin{array}{l}\text { 1. Viewing multimedia laboratory work № } 1 \\
\text { and video lessons № } 1,2 \text {, presented in the } \\
\text { Moodle system. } \\
\text { 2. Test control № } 1 \text { in the Moodle system. }\end{array}$ \\
\hline Laboratory work № 2 & $\begin{array}{l}\text { Choosing and installation of the } \\
\text { ship overlap beam systems in } \\
\text { CADMATIC CAD taking into } \\
\text { account the requirements for overall } \\
\text { longitudinal strength }\end{array}$ & $\begin{array}{l}\text { 1. Viewing multimedia laboratory work № } 2 \\
\text { and video lessons № 4, 9, presented in the } \\
\text { Moodle system. } \\
\text { 2. Test control № } 2 \text { in the Moodle system. }\end{array}$ \\
\hline Laboratory work № 3 & $\begin{array}{l}\text { Changing the strength of the ship's } \\
\text { overlap by editing the beam system } \\
\text { in CADMATIC CAD }\end{array}$ & $\begin{array}{l}\text { 1. Viewing multimedia laboratory work № } 3 \\
\text { and video lessons № 4, 8, presented in the } \\
\text { Moodle system. } \\
\text { 2. Test control № } 3 \text { in the Moodle system. }\end{array}$ \\
\hline Laboratory work № 4 & $\begin{array}{l}\text { Reducing the metal consumption of } \\
\text { hull structures by creating holes in } \\
\text { CADMATIC CAD }\end{array}$ & $\begin{array}{l}\text { 1. Viewing multimedia laboratory work № } 4 \\
\text { and video lessons № } 3,5 \text {, presented in the } \\
\text { Moodle system. } \\
\text { 2. Test control № } 4 \text { in the Moodle system. }\end{array}$ \\
\hline Laboratory work № 5 & $\begin{array}{l}\text { Increasing the strength of the ship's } \\
\text { overlap, weakened by the hole, in } \\
\text { CADMATIC CAD }\end{array}$ & $\begin{array}{l}\text { 1. Viewing multimedia laboratory work № } 5 \\
\text { and video lesson № 6, presented in the } \\
\text { Moodle system. } \\
\text { 2. Test control № } 5 \text { in the Moodle system. }\end{array}$ \\
\hline Laboratory work № 6 & $\begin{array}{l}\text { Reducing the stress concentration at } \\
\text { the joints of hull structures in } \\
\text { CADMATIC CAD }\end{array}$ & $\begin{array}{l}\text { 1. Viewing multimedia laboratory work № } 6 \\
\text { and video lesson № 7, presented in the } \\
\text { Moodle system. } \\
\text { 2. Test control № } 6 \text { in the Moodle system. }\end{array}$ \\
\hline Laboratory work № 7 & $\begin{array}{l}\text { Ensuring the inflexibility of the } \\
\text { ship hull by installing frames in } \\
\text { CADMATIC CAD }\end{array}$ & $\begin{array}{l}\text { 1. Viewing multimedia laboratory work № } 7 \\
\text { and video lesson № } 6 \text {, presented in the } \\
\text { Moodle system. }\end{array}$ \\
\hline
\end{tabular}




\begin{tabular}{|c|c|l|}
\hline Laboratory work № 8 & $\begin{array}{c}\text { Improving the inflexibility of the } \\
\text { ship plate free edges in } \\
\text { CADMATIC CAD }\end{array}$ & $\begin{array}{l}\text { 2. Test control № 7 in the Moodle system. } \\
\text { 1. Viewing multimedia laboratory work № 8 } \\
\text { and video lessons № 6, 7, presented in the } \\
\text { Moodle system. } \\
\text { 2. Test control № 8 in the Moodle system. }\end{array}$ \\
\hline Laboratory work № 9 & $\begin{array}{l}\text { The ship section design } \\
\text { documentation development in } \\
\text { CADMATIC CAD }\end{array}$ & $\begin{array}{l}\text { 1. Viewing multimedia laboratory work № 9 } \\
\text { and video lessons № 10, presented in the } \\
\text { Moodle system. } \\
\text { 2. Test control № 9 in the Moodle system. }\end{array}$ \\
\hline Graduation work & $\begin{array}{l}\text { Development of a three- } \\
\text { dimensional model of the ship } \\
\text { section in CADMATIC CAD }\end{array}$ & $\begin{array}{l}\text { 1. Execution of laboratory workshop. } \\
\text { 2. Control testing in the Moodle system. } \\
\text { 3. Study of design documentation for the } \\
\text { ship section. }\end{array}$ \\
\hline
\end{tabular}

This course gives the possibility to obtain practical engineering skills in developing a three-dimensional hull structure model considering the customer requirements and issuing the design documentation for the ship's sections using CADMATIC tools. It should be clarified that, as mentioned above, a similar laboratory workshop with certification work can be performed in any other shipbuilding CAD. In particular, such workshops were earlier also successfully implemented by the authors in the TRIBON system.

Subsequently, the proposed model formed the basis of the pilot project "Development and testing of specialised multimedia courses in advanced ship engineering". The project aimed to provide continuous distance education in the context of the COVID-19 pandemic and after its end. This project was successfully implemented with the support of Ship Design and Engineering Bureaus, such as C-Job Mykolaiv, MDEM and AMICO-Oil. The project involved an intern who took the proposed course for three months in a remote mode. At the end of the period, the intern independently carried out the final work on the three-dimensional modelling of the ships' hull block (also remotely), the successful completion of which was an indicator of the high efficiency of the developed model.

Table 4 shows the distribution of hours that were planned for the course "Basics of Ship Engineering" in a remote mode, and hours that were actually spent on the tasks of the course by the intern. The planned hours were determined based on the hours spent by students of the course in full-time study in the classroom.

Table 4

The distribution of hours of the pilot project "Development and testing of specialised multimedia courses in advanced ship engineering"

\begin{tabular}{|c|c|c|c|c|c|c|c|}
\hline \multirow{2}{*}{ Project content } & \multicolumn{3}{|c|}{ Practice/ consultation/ certification (hours) } & \multicolumn{2}{c|}{ Date } \\
\cline { 2 - 8 } & Plan & Fact & Consultation & $\begin{array}{c}\text { Self- } \\
\text { preparation }\end{array}$ & Defense & Plan & Fact \\
\hline Content module 1 & $\mathbf{5 8}$ & $\mathbf{5 6}$ & & & & & \\
\hline Lecture 1 & 7 & 7 & 2 & 5 & & 07.09 .20 & 07.09 .20 \\
\hline Lecture 2 & 7 & 7 & 2 & 5 & & 10.09 .20 & 10.09 .20 \\
\hline Lab work 1 & 8 & 6 & 4 & 2 & 2 & 15.09 .20 & 15.09 .20 \\
\hline Lecture 3 & 7 & 7 & 2 & 5 & & 16.09 .20 & 16.09 .20 \\
\hline Lab work 2 & 8 & 9 & 5 & 2 & 2 & 18.09 .20 & 18.09 .20 \\
\hline Lecture 4 & 7 & 7 & 2 & 5 & & 21.09 .20 & 21.09 .20 \\
\hline Lab work 3 & 8 & 7 & 3 & 2 & 2 & 22.09 .20 & 22.09 .20 \\
\hline Zoom defense & 6 & 6 & 2 & 4 & & 24.09 .20 & 24.09 .20 \\
\hline (documentation set 1) & $\mathbf{6}$ & $\mathbf{6 1}$ & & & & & \\
\hline Content module 2 & $\mathbf{6 2}$ & 2 & 4 & & 25.09 .20 & 25.09 .20 \\
\hline Lecture 5 & 6 & 6 & 6 & 4 & & 28.09 .20 & 28.09 .20 \\
\hline Lecture 6 & 6 & 6 & 2 & 2 & 2 & 29.09 .20 & 29.09 .20 \\
\hline Lab work 4 & 8 & 8 & 4 & 2 & & 01.10 .20 & 01.10 .20 \\
\hline Lecture 7 & 5 & 5 & 2 & & &
\end{tabular}




\begin{tabular}{|c|c|c|c|c|c|c|c|}
\hline Lecture 8 & 5 & 5 & 2 & 3 & & 01.10 .20 & 01.10 .20 \\
\hline Lab work 5 & 8 & 7 & 4 & 2 & 2 & 02.10 .20 & 05.10 .20 \\
\hline Lecture 9 & 5 & 5 & 2 & 3 & & 07.10 .20 & 07.10 .20 \\
\hline Lecture 10 & 5 & 5 & 2 & 3 & & 07.10 .20 & 07.10 .20 \\
\hline Lab work 6 & 8 & 8 & 4 & 2 & 2 & 08.10 .20 & 08.10 .20 \\
\hline $\begin{array}{c}\text { Zoom defense } \\
\text { (documentation set 2) }\end{array}$ & 6 & 6 & 2 & 4 & & 09.10 .20 & 09.10 .20 \\
\hline Content module 3 & $\mathbf{6 0}$ & $\mathbf{6 0}$ & & & & & \\
\hline Lecture 11 & 6 & 6 & 2 & 4 & & 12.10 .20 & 12.10 .20 \\
\hline Lecture 12 & 6 & 6 & 2 & 4 & & 12.10 .20 & 12.10 .20 \\
\hline Lab work 7 & 8 & 7 & 4 & 2 & 2 & 13.10 .20 & 13.10 .20 \\
\hline Lecture 13 & 6 & 6 & 2 & 4 & & 15.10 .20 & 15.10 .20 \\
\hline Lab work 8 & 8 & 8 & 4 & 2 & 2 & 16.10 .20 & 19.10 .20 \\
\hline Lecture 14 & 6 & 6 & 2 & 4 & & 21.10 .20 & 21.10 .20 \\
\hline Lecture 15 & 6 & 6 & 2 & 4 & & 21.10 .20 & 21.10 .20 \\
\hline Lab work 9 & 8 & 9 & 5 & 2 & 2 & 23.10 .20 & 23.10 .20 \\
\hline $\begin{array}{c}\text { Zoom defense } \\
\text { (documentation set 3) }\end{array}$ & 6 & 6 & 2 & 4 & & 27.10 .20 & 27.10 .20 \\
\hline $\begin{array}{c}\text { Individual graduation } \\
\text { work }\end{array}$ & $\mathbf{5 0}$ & $\mathbf{4 6}$ & & & & & \\
\hline Part 1 & 6 & 4 & 2 & 2 & & 29.10 .20 & 02.11 .20 \\
\hline Part 2 & 6 & 4 & 2 & 2 & & 05.11 .20 & 05.11 .20 \\
\hline Part 3 & 4 & 4 & 2 & 2 & & 10.11 .20 & 12.11 .20 \\
\hline Part 4 & 6 & 6 & 4 & 2 & & 17.11 .20 & 16.11 .20 \\
\hline Part 5 & 6 & 5 & 4 & 2 & & 18.11 .20 & 18.11 .20 \\
\hline Part 6 & 6 & 6 & 4 & 2 & & 23.11 .20 & 23.11 .20 \\
\hline Part 7 & 4 & 5 & 4 & 2 & & 25.11 .20 & 25.11 .20 \\
\hline Part 8 & 6 & 6 & 4 & 2 & & 30.11 .20 & 30.11 .20 \\
\hline $\begin{array}{c}\text { Zoom defense } \\
\text { working and design } \\
\text { documentation set 4) }\end{array}$ & 6 & 6 & 2 & 4 & & 30.11 .20 & 30.11 .20 \\
\hline Certificate & $\mathbf{2 3 0}$ & $\mathbf{2 2 3}$ & $\mathbf{1 0 1}$ & $\mathbf{1 1 0}$ & $\mathbf{1 8}$ & 10.12 .20 & 11.01 .21 \\
\hline & & & & & & \\
\hline
\end{tabular}

As seen from the table, some tasks were performed faster than planned during the testing of the developed training model (discrepancies in table values are highlighted). And only in three cases, students needed a little more time than planned to complete the practical tasks of the course entirely in remote mode. All these indicate that the proposed model of implementing distance learning of the basics of ship engineering through modern information systems fully meets the requirements that were put forward to it, namely:

- distance learning in no way affects the general terms of study (some deviations occur, because each student is individual in terms of learning the material);

- in the distance format the student obtains practical engineering skills at the same level as in full-time study;

- the distance training course is realized with proper data protection, thereby ensuring the commercial security requirements of leading CAD suppliers.

\section{CONCLUSIONS AND PROSPECTS FOR FURTHER RESEARCH}

The analysis of published information on the paper topic has shown that most of the current online courses that are part of distance education are only electronic versions of the course material taught full-time. Thus, they do not provide even a tiny percentage of practical skills relevant to the engineering speciality. Simultaneously, even the existing models of remote laboratory work cannot be applied to students and interns receiving training in ship 
design. The main obstacles are the high cost of licences for modern shipbuilding CAD, the lack of security for this type of system in open VPN mode, and commercial risks for CAD suppliers related to carrying out real-time professional training work in a safe remote format.

An analysis of the shortcomings of the existing distance education models has made it possible to establish a new model of distance learning for shipbuilding students. They, as future designers, gain basic knowledge of the up-to-date ship engineering with the possibility of carrying out practical laboratory works in real-time mode with simultaneous use of three modern systems: Moodle, CADMATIC and TeamViewer. However, application of alternative software platforms does not ultimately change the general principle of the developed learning scheme.

Based on the presented model, the students were provided with full practical skills in ship design using modern three-dimensional CAD via distance learning under the teacher's full online supervision. The described course prepares the trainees for work at shipbuilding companies in initial engineering positions in ship hull design. The proposed approach can be used for the development and use of other naval engineering professional training courses. The proposed model can be used in the COVID-19 pandemic and beyond.

The pilot project we have implemented and the processing of the internship training results have confirmed that the model of remote education developed by the authors is effective in real-time distance engineering education. It allows obtaining practical engineering skills meeting employers' requirements to the use of modern information systems. The obtained results also completely meet the commercial safety requirements of the leading suppliers of shipbuilding systems CAD / CAM / CAE. The model, which was the basis of this project, can be used in any other areas of distance education.

In the future, it is worth considering in more detail the possibilities of additional protection of data stored on the server when using the developed model, as well as the features of work with analogues of software applications included in the model.

\section{REFERENCES (TRANSLATED AND TRANSLITERATED)}

[1] I. Adamova, and T. Holovachuk, "Distance learning: a modern look at the benefits and challenges", Vytoky pedahohichnoi maisternosti, vol. 10, pp. 3-6, 2012. (in Ukrainian)

[2] F. V. Ferraro, F. I. Ambra, L. Aruta, and M. L. Iavarone "Distance Learning in the COVID-19 Era: Perceptions in Southern Italy", Educ. Sci., 2020. [Online]. Available: http://www. Mdpi.com/journal/education. Accessed on: Feb. 17, 2021. (in English)

[3] S. Brammer, and T. Clark, "COVID-19 and Management Education: Reflections on Challenges, Opportunities, and Potential Futures", British Journal of Management, vol. 31, pp. 453-456, 2020. (in English)

[4] Yu. Bodnar, and Yu. Salizhenko, "Sit and study: why online education wins in the world and in Ukraine", 2016. [Online]. Available: http://www.platfor.ma/mazazine/text-sq/projects/traditional-vs-onlineeducation. Accessed on: Feb. 3, 2021. (in Russian)

[5] V. Arkorful, and N. Abaidoo, "The role of e-learning, advantages and disadvantages of its adoptions in higher education", International Journal of Instructional Technology and distance learning, vol. 12, no. 1, pp. 29-43, 2015. (in English)

[6] D. Evans, and T. Shortall, "Student's views on the advantages and disadvantages of Open Distance Learning versus traditional On-Campus Learning in Master's degree course for languages teachers in a British University", J Nurs Studies NSNG, vol. 10, no. 1, pp. 21-30, 2011. (in English)

[7] A. N. Korneev, andE. V. Tolokonnikova, Distance learning: the future of education development, Uchebno-metodicheskoe posobie. Moskva, Russian Federation: Mir nauki, 2019. (in Russian)

[8] L. V. Shtykhno, "Distance learning as a promising area of modern education development", Young Scientist, no. 6 (33), pp. 489-493, 2016. (in Ukrainian)

[9] S. S. Kizim, "Peculiarities of would-be teachers' professional training with electronic educational resources", Information Technologies and Learning Tools, vol. 65, no. 3, pp. 115-132, 2018. doi: https://doi.org/10.33407/itlt.v65i3.2266. (in English) 
[10] O. V. Lemeshko, O. V. Yankovets, V. V. Lemeshko, A. V. Yankovets, and I. O. Basaraba, "Massive open online courses as a means of border guards' professional competence development", Information Technologies and Learning Tools, vol. 75, no 1, pp. 279-293, 2020. doi: https://doi.org/10.33407/itlt.v75i1.2969. (in English)

[11] V. V. Pogorilyi, L. V. Dudikova, O. Hr. Yakymenko, S. A. Poyda, and B. F. Koval, "Improvement of learning outcomes in educational process of intern-pharmacists using distance learning elements", Information Technologies and Learning Tools, vol. 76, no 2, pp. 236-249, 2020.(in English)

[12] "Online training - 10 best services in the world", 2014. [Online]. Available: http://www.openeducation.net/services/obuchenie-onlajn-10-luchshih-v-mire-servisov.Accessed on: Jan. 28, 2021. (in Russian)

[13] G. Durak, and M. Alaisi, "Learner Views about a Distance Educational Course", Contemporary educational Technology, no. 7 (1), pp. 85-105, 2016. (in English)

[14] I. Leontyeva, "Modern Distance Learning Technologies in Higher Education: Introduction Problems", Eurasia Journal of Mathematics, Science and Technology Education, no. 14 (10), 2018. [Online]. Available: http://doi.org/10.29333/ejmste/92284. Accessed on: Mar. 5, 2021. (in English)

[15] A.V. Novikov, A. A. Barmin, A. A. Mudrova, and Yu. V. Yasinskaya, "System analyses of the features of using informational models in shipbuilding", Journal of Physics: Conference Series, 2019. [Online]. Available: http://iopscience.iop.org/article/10.1088/1742-6596/1333/3/032092.pdf. Accessed on: Mar. 2, 2021.(in English)

[16] A. M. Anisimov, Work in the Moodle distance learning system, Uchebnoe posobie. Kharkiv, Ukraine: KhNAGKh, 2009. (in Russian)

[17] "Nupas-Cadmatic shipbuilding CAD: a look at the possibilities", 2015. [Online]. Available: http://www.remmag.ru/upload_data/files/2015-03/NCG.pdf. Accessed on: Nov.9, 2020. (in Russian)

[18] D. Basvin, "TeamViewer growth powered by pandemic work-from-home", REUTERS, 2020. [Online]. Available: http://reuters.com/article/us-teamviewer-results-idUSKBN220OJO. Accessed on: Mar. 8, 2021. (in English)

[19] D. Razumovskij, "How to replace TeamViewer?", Komp yuterra - zhurnal o sovremennykh tekhnologiyakh, 2019. [Online]. Available: http://computerra.ru/242957/chem.-zamenit-teamviewer. Accessed on: Dec. 21, 2020. (in Russian)

[20] V. M. Tomashevskyi, Yu. L. Novikov, andP. A. Kaminska, "Review of the current state of distance learning systems", Naukovi pratsi Chornomorskoho derzhavnoho universytetu imeni Petra Mohyly, vol. 160, no. 148, pp. 146-157, 2011.(in Ukrainian)

[21] Yu. D. Zhukov, A. Yu. Gajdaj, O. A. Kudin, N. A. Emecz, and O. N. Lobanova, "The use of multimedia teaching aids in teaching the basics of ship engineering", Mezhdunarodnyj zhurnal ob innovacziyakh $v$ sudostroenii "Sudostroenie I morskaya infrastruktura", № 1 (3), pp. 32-45, 2015. (in Russian)

[22] Yu. D. Zhukov, A. Yu. Gajdaj, and O. N. Lobanova, Fundamentals of the latest ship engineering. Hull structures, Uchebnoe posobie. Nikolaev, Ukraine: V. V. Torubara, 2020. (in Russian)

[23] W. K. ElSaid, "Securing Sensitive Digital Data in Educational Institutions using Encryption Technology", International Journal of Computer Science and Information Security, vol. 16, no. 6, pp. 1-8, 2018. [Online].

Available: https://www.academia.edu/36998342/Securing_Sensitive_Digital_Data_in_Educational_Institutions_usin g_Encryption_Technology. Accessed on: Mar. 3, 2021. (in English)

Text of the article was accepted by Editorial Team 27.04.2021.

\title{
СУЧАСНИЙ СТАН ТА ПЕРСПЕКТИВИ ВИКОРИСТАННЯ ЗАСОБІВ ДИСТАНЦІЙНОГО НАВЧАННЯ ПІД ЧАС ВИВЧЕННЯ КОРАБЕЛЬНОЇ IHЖЕНЕРIÏ
}

\author{
Жуков Юрій Даниїлович \\ доктор технічних наук, професор, професор кафедри морського приладобудування \\ Національний університет кораблебудування імені адмірала Макарова, м. Миколаїв, Україна \\ ORCID 0000-0002-7454-8007 \\ prof.zhukov@gmail.com
}




\title{
Гайдай Ганна Юріївна
}

кандидат технічних наук, доцентка кафедри морського приладобудування

Національний університет кораблебудування імені адмірала Макарова, м. Миколаїв, Україна

ORCID 0000-0002-2516-7080

russish999@gmail.com

\section{Кудін Олег Олексійович}

викладач кафедри морського приладобудування

Національний університет кораблебудування імені адмірала Макарова, м. Миколаїв, Україна

ORCID 0000-0003-3334-0012

oleg.alekseevich.kudin@gmail.com

\begin{abstract}
Анотація. Основну увагу в публікації приділено виявленню переваг та недоліків систем дистанційної освіти 3 точки зору сучасних потреб у практичних навичках майбутніх фахівців, особливо в технічній галузі. На основі аналізу недоліків існуючих моделей дистанційного навчання в контексті пандемії було обгрунтовано необхідність у принципово новій системі дистанційної освіти. Модель, що було запропоновано, дозволяє студентам i стажистам суднобудівного профілю засвоїти теоретичні основи суднобудівного проєктування та інжинірингу, а також виконати всі поставлені завдання, набуваючи практичних навичок роботи в спеціалізованих пакетах сучасних суднових САПР повністю дистанційно. Цю модель було протестовано з використанням технології обміну даними між трьома сучасними інформаційними платформами: Moodle, CADMATIC ${ }^{\text {тм }}$ i TeamViewer. Були виявлені переваги даної моделі дистанційного навчання: можливість набуття практичних навичок у галузі сучасних систем автоматизованого проєктування з будь-якої точки світу шляхом безпосередньої взаємодії учня та викладача в режимі реального часу. На основі представленої моделі був розроблений відповідний підхід до інженерної освіти, що дозволяс студентам придбати необхідні практичні навички і початковий досвід у галузі суднобудування з використанням сучасних тривимірних САПР у дистанційному режимі. У межах цього курсу слухачі готуються до роботи в суднобудівних і виробничих компаніях на початкових інженерно-технічних посадах, а саме в галузі проєктування корпусів суден, розробки конструкційних цифрових близнюків і розробки виробничої інформації. В "Інституті новітньої корабельної інженерії" Національного університету кораблебудування імені адмірала Макарова було здійснено експериментальний проєкт "Розробка та випробування спеціалізованих мультимедійних курсів по просунутому суднобудуванню". Результати проєкту свідчать про високу ефективність використання освітнього підходу, який було запропоновано, до підготовки інженерів 3 урахуванням сучасних вимог роботодавців до майбутніх проєктувальників і вимог комерційної безпеки постачальників суднобудівних САПР. Актуальність цього результату виправдано як під час пандемії COVID-19, так і в майбутньому.
\end{abstract}

Ключові слова: дистанційне навчання; проєктування суден; автоматизоване проєктування; модель навчання; інженерна освіта; цифрові близнюки.

\section{(c)) BY-NC-SA}

This work is licensed under Creative Commons Attribution-NonCommercial-ShareAlike 4.0 International License. 